\title{
Stimulating Kosovo
}

\section{Borut Grgic and Jana Urh *}

The violence that erupted in Kosovo in mid-March after a brief period of general stability is a stark reminder that much remains to be done before perpetual security in the region becomes a de facto reality. Unfortunately, there is a real lack of ideas on what to do next on the part of the international community. The recent proposal from Belgrade - the so-called Belgrade Plan - has only intensified what now is a headless race towards a solution. The problem is two-fold: on the one hand, the international community is moving in the direction of decentralization, particularly along ethnic lines, while on the other hand no one is considering the economic and social impact this will have on a system which is already burdened by massive economic, social, democratic, and educational poverty, and basically on the verge of total collapse.

We have seen this approach at work before, and we are seeing it again now in Bosnia. Despite almost ten years of ongoing reform processes and international money poured into the reconstruction, economic revival, and democratization of the country, realistically, Bosnia remains as far from self-sustainability and thus Euro-Atlantic integration as Kosovo. The Dayton "monster" (the institutional framework drafted to provide a territorial solution to the Bosnia crisis) is today a major, if not the main, obstacle to the long-term viability of the Bosnian state. Why repeat the mistake in Kosovo?

The goal should be not to further divide communities, only to later struggle in finding ways to once again unite them. The goal should be to figure out how to offset the most pressing short-term problems exacerbating the situation in Kosovo, while laying the groundwork for a functional (in the long run), economically viable, and prosperous Kosovo. Politically engineered partition through decentralization of power does not do. Rather, the answer for now is in a systematic plan - a set of short-term policy adjustments that will focus on creating jobs, improving the leadership structure within UNMIK, ${ }^{1}$ strengthen PISG, complete the privatization process, and increase investment in education - and a vision for medium- and long-term priorities and objectives. Simplifying the problem in Kosovo to standards before status is outrageously shortsighted. Equally sinister, then, is the proposed solution: status before standards.

* Borut Grgic is Senior Fellow at the Atlantic Council in Washington D.C., and co-founder of Onamics LLC. Jana Urh is assistant professor in the Faculty of Social Sciences at the University of Ljubljana.

1 The mission lacks strong leadership within the SRSG office that is able to effectively manage and co-ordinate both resources and projects between the four Pillars. The office of SRSG could certainly do more if the Special Representative had the powers vested in him to dismiss radical leaders, push forward stalling reforms (particularly relevant is continued privatization), and improve coordination. Strong OHR in Bosnia, for example, serves as a vehicle for understanding, coordinating, and facilitating economic reforms, which are being prepared on the technical level by international organizations. 
Final status is certainly an issue, but it is not the pressing or central problem at this point. The Serbian and Albanian communities disagree over the question of final status, but they all agree on the socio-economic misery looming over Kosovo.

Independence for Kosovo in the long run is inevitable, and probably even logical. One could argue that the present efforts to develop a functional and self-sustainable institutional unit are an implied form of recognition of Kosovo's statehood. ${ }^{2}$ Certainly the fact that representatives from PISG are participating in international conferences, and are on an official level engaging with other state leaders (even leaders from Belgrade) goes toward proving this point.

At present, however, Kosovo does not have the necessary institutional capabilities to be fully independent. One scholar has argued, "Kosovo should use this interim period to build a critical leadership base and gain the necessary expertise for successful integration into the global market economy."3 Short-term priorities must remain focused on capacity building. Kosovo's public infrastructure-for example, the transportation network - is in a state of disarray. Electric power supply is inconsistent, while labor is uneducated and unskilled. Of those employed, an estimated 42.8 percent of them work in subsistence agriculture. ${ }^{4}$ This is not an investor-friendly environment, to say the least, and foreigners are more likely to take their capital to Romania, Bulgaria, and Macedonia.

Many dismiss this concern by pointing to the Albanian Diaspora, and arguing that it would assume the role of the primary foreign investor in Kosovo, which is entirely possible, and to an extent even probable. There are a few counterpoints to consider, however. For one, Palestine has been on a path towards independence for over a decade now, yet the inflow of Diaspora money has been meager. Rather than investing in Palestine's future, the Palestinian Diaspora has dived into political horse-trading with Arafat and his Fatah group, competing for power and control. This same animosity and struggle for power seems to be in the making in Kosovo. Remittances are already down, while investment in the private production sector by the Kosovar Albanian Diaspora is much too small to call it a smashing success. Second, the Kosovar Albanian Diaspora, while emotionally attached to the "homeland," is probably also a rational investor group, keeping cost-benefit considerations at the forefront.

The other issue to consider is the time loss that occurs with every change in the administrative structure. A decision to move from standards before status to standards with status or even status before standards would require a new UN Security Council resolution, and a new structure for the international presence in Kosovo. A transfer of

2 See Ian Brownlie, "Implied Recognition," in Principles of Public International Law, $6{ }^{\text {th }}$ ed. (New York: Oxford University Press, 2003), 94.

3 Borut Grgic conversation with Robert Muharremi, Legal Counsel at UNMIK Pillar IV, and former Legal Counsel to Prime Minister of Kosovo Rexhepi.

4 Gerald Knaus, "The New Geopolitics of the Balkans," May 2004. Paper presented at the $10^{\text {th }}$ Thessaloniki Forum, May 24-25, 2004. 
responsibilities and authority from the $\mathrm{UN}$ to the EU, as is advocated by some, ${ }^{5}$ would also require a new Security Council resolution and a major adjustment to the Pillar structure currently in place. This means that the international community, rather than continuing with the unfinished process of privatization and job-creation, will be spending invaluable time, political capital, and financial resources on the redefinition and reconstruction of its mission in Kosovo.

The argument that Kosovo cannot successfully be transformed into a multiethnic state sounds rather un-European, and it is surprising to find so many EU states so prepared to support this idea. While it is true that multiethnic dialogue has taken a step backwards following the mid-March outburst of violence, cooperation between Serbs and Albanians continues. ${ }^{6}$ Second, while it is true that many Kosovo Serbs continue looking towards Belgrade for their political affiliation and representation, many are now turning to Pristina with a determination to participate and affect decision-making at the Kosovo level. ${ }^{7}$

\section{Ethnic Division of Kosovo: Milošević's Political Agenda and its Consequences}

That there is much to be learned from the history of ethnic hatred in the Balkans is a commonplace, as if history itself would create mythical personalities, glorious victories, or inherent hatred. Historical data can thus provide enough proof for painting Balkans as people who simply hate each other too much to live together. But then again, it can also provide an interpretation according to which political actors, not mythical personalities, are just smart enough to pursue feasible political goals, or influential enough to teach others how to create history in the Balkans.

Policies of division and authoritarian rule were an integral part of Slobodan Milošević's political agenda. His political career flourished at the expense of Kosovo's political turmoil, as well as its lack of satisfactory economic development and an adequate political framework to amortize social frustrations in the 1980s. One of his main political tasks was to convince enough people that Serbs in Kosovo were threatened by Albanians, and that Albanian separatism represented a threat to Yugoslav stability. ${ }^{8} \mathrm{He}$ perfected a policy of territorial division based on ethnic principle, also known as "bal-

5 See conference proceedings, "Rethinking the Balkans," Balkan Forum 17-18 June 2004, Bertlesmann Foundation.

6 Borut Grgic conversations with a Serb Deputy Mayor of Djilan, Dragan Petković, and Mayor Lufti Haziri.

7 Ibid.

8 For comprehensive presentation of Serbian policy in the 1980 s see Eric D. Gordy, The Culture of Power in Serbia: Nationalism and the Destruction of Alternatives (University Park, PA: Penn State University Press, 1999); and Tim Judah, The Serbs: History, Myth, and the Destruction of Yugoslavia (New Haven, CT: Yale University Press, 1997). 
kanization," or "breaking up the territory into small, often hostile units." did not, however, balance economic reform and restructuring with political reforms.

His platform was based on a rational manipulation of objective political facts and national sentiments. To claim that Milošević was a nationalist is to argue that he believed in a rationality of optimizing delicate historical fictions of "ancient hatred" in a specific political and economic context. The 1974 Yugoslav Constitution made Kosovo an autonomous province of the Socialist Federal Republic of Yugoslavia. More importantly, it made the province an equal constitutional element in the Federation as one of eight federal units. Although not yet a Republic, its authority within the Federation was equal to that of Serbia, which gave both Albanian and Serbian political extremists an even start for ethnically-based argumentation.

Population figures were especially useful for the promotion of Serbian fears and frustrations in the poorest of the federal units. By 1981, Albanians constituted 77 percent of the population in Kosovo, due to a high fertility rate. Serb emigration by 1985 also increased in response to pressure and intimidation by extremist Albanians and stagnant economic prospects; making economic development in the province worse, the Serbs who left were better educated and technically trained than the Albanians who moved in. ${ }^{10}$

Extremist Albanians also made no bones about desiring an "ethnically clean" Kosovo, which was in accordance with Milošević's strategic goals. The "National Liberation of Kosovo-NLA" movement developed, along with other extreme underground Albanian groups, and all played along with proclamations on ethnic divisions and territorial claims.

The process of abolishing Kosovo's autonomy began in March 1989 via amendments to the Serbian constitution that gave Serbia direct control over Kosovo. These changes were approved by the Kosovo Parliament after it had been purged of all opponents of "centralization of power." On 28 June 1989, also known as Vidovdan, a political rally was held at Kosovo Polje to commemorate the Serbian defeat at the hands of the Turks in 1389. Thousands of photos and posters of Milošević were displayed, together with his promise to defend the rights of Serbian ethnicity in specific territories. "They want to take away Serbian and Yugoslav Kosovo. They want this, but they won't be able to," was one of the promises to the people made by Milošević. After Vidovdan 1989, Milošević became considered not only in Kosovo, but in all of Serbia as well, as the first Serbian leader since World War II to have defended Serbia's interests within the rapidly disintegrating SFRY.

The proclamation of the "principle of multiethnicity" lay at the core of Serbian policy towards Kosovo since 1990, but it was used as a means to divide the population and control it. As early as March 1990 the Serbian Parliament adopted the "Program

9 This interpretation of balkanization is according to Maria Todorova's famous Imagining the Balkans (New York: Oxford University Press, 1997).

${ }^{10}$ For additional argumentation see Marina Blagojevic, "Iseljavanje Srba sa Kosova: trauma ili katarza," in Srpska strana rata, ed. Nebojsa Popov (Belgrade: Republika, 1996). 
for Achieving Peace, Freedom, and Equality in Kosovo." Its proclaimed goal was "the peaceful co-existence of all ethnic groups in Kosovo," together with the identification of Albanian separatists as the main threat to this goal. Dr. Nebojsa Covic, the architect of the political administration of Kosovo within the Serbian state, made several plans on how to create a working combination for the "division" of Kosovo plus "multi-ethnicity" within the Serbian administrative and political system. The Council of Europe's 2003 "Recommendation for decentralization of Kosovo" describes the last of Covic's proposals as quite concrete in detail, "but completely at variance with the idea of multiethnic Kosovo as it envisaged separate administration for the Kosovar Serb community, with strong links to the Serbian authority."11

When, at the end of April 2004, the Serbian government introduced "The Belgrade Plan," a long-term, already seen vision of future political development of Kosovo reappeared. ${ }^{12}$ The policy of territorial and ethnic division is again the "Ariadne's clue" of Serbian politics. Population figures, numbers of the deprived and frightened, social dissatisfaction, and poor economic prospects are yet again being used to bolster the policy of "balkanization." Now it is delivered not only with multi-ethnicity as a means to a specific end goal, but also with a unique interpretation of other "European" concepts such as decentralization and subsidiarity.

The Belgrade Plan envisages the establishment of an "autonomous region" for the Serbian population in Kosovo: "Serbs would be entitled to parts of the territory that links in a natural way Serb-dominated settlements, in which they previously did not make up a majority." The political autonomy of the region would be established according to the principles of subsidiarity and decentralization, which would consolidate political links with Belgrade and result in territorial, personal, and cultural autonomy for the Serbs. Refugees and displaced persons are the key and necessary element of the plan. The figure of 200,000 people displaced since 1999 indicates the extent to which displacement serves as the modus operandi for the division, together with the principle of "just compensation." "13 The Serbian plan is based on the same concepts as the Council of Europe's recommendation for the decentralization of Kosovo, but the recommended policy and basic principles could not be farther apart.

Multiethnicity was and remains part of the calculus of political manipulation within the paradigm of "balkanization," which the Serbian leadership is still promoting; Belgrade is making a serious, and some would even argue a final push towards an ethnically-based partition of Kosovo. Following the violence this past March, Kostunica said: "I trust it is clear to everyone that a multiethnic Kosovo is unworkable, more so even than the communist utopia of a society without classes. If the latter were still feasible, a multiethnic society in Kosovo is not."14

11 See http://www.cmline.coe.int.

12 "A plan for the political solution to the situation in Kosovo and Metohija," available at http://www.srbija.sr.gov.yu.

13 The 200,000 number is not conclusive, which further raises doubts over Serbia's motives.

14 VIP, 29 March 2004. 
And the paradox? Any radical change of approach at this point will only further exacerbate the very problem that is contributing to international failure in Kosovo. And this problem lies not in ethnic hatred, but in lack of employment on the local market. It is high time for a new political paradigm in the Balkans, one that is not obsessed with divisions and creation of borders between people of different ethnic backgrounds, but focused on the creation of a sound economic base for multiethnicity to start thriving in the field and among the people.

If the creators of EU foreign policy are serious about the "Europeanization" of Kosovo and its neighborhood, political wrangling about standards, status, or independence will soon have to be turned upside down. The economy must become a precondition, cause, and effect of every political agreement — in short, it must be the theme song of a new paradigm for international engagement in Kosovo.

\section{Stimulating Kosovo's Job Market: Offsetting Risk}

With unemployment hovering between 50 and 60 percent, Kosovo has no realistic short- or medium-term prospects for positive economic development. ${ }^{15}$ Kosovo's GDP is growing at an unsatisfactory rate, a little under 3 percent for the fiscal year 2002 and 2003. ${ }^{16}$ At the same time, Kosovo continues to add prospective employees at a faster rate than the market can absorb. Unless something changes, the obvious expected medium-term effect is higher unemployment. In addition, the higher rate of return of Kosovar refugees from Europe, combined with stricter EU visa regulations that are making it harder for Kosovars to leave, should further exacerbate the problem of unemployment in the medium term.

The main threat to Kosovo's security today is not external. Serbia is financially and militarily too weak to pursue a significant armed campaign intended at reestablishing control over Kosovo. Even if it could, the question remains of whether such an adventure would be profitable in the first place in terms of gained political points versus those lost because of the enormous financial costs involved. Rather, the major security problem lies in the nexus between high unemployment, inadequate education and skills, low private investment in the production sector, and ineffective leadership. In

15 Labor, along with Capital and Technology, is a key determinant of medium and long-run growth. The production function $-\mathrm{Y}=\mathrm{F}(\mathrm{N}, \mathrm{K}, \mathrm{A})$, where $\mathrm{N}=$ labor, $\mathrm{K}=$ capital and $\mathrm{A}=$ technology - shows how much output can be produced from given amounts of labor, capital, and technology. The $\mathrm{N}$ factor for Kosovo is high, while $\mathrm{N}^{*}$ is low $\left(\mathrm{N}^{*}=\right.$ the actual level of employment, meaning the number of eligible workers minus those unemployed), which means that the actual Y (output or GDP) is much lower than it could potentially be. The question to consider is this: Through what measures can Kosovo be moved closer to the natural rate of unemployment?

16 According to the 2003 Annual Report published by the Banking and Payments Authority of Kosovo, GDP in 2002 was 1,279 million EUR. In 2003, the GDP was 1,317 million EUR. 
addition, the multidimensional power struggle is making Kosovo a rather convenient transit point for organized international criminal networks. ${ }^{17}$

In order to create jobs, a set of short-term macroeconomic adjustments, as well as changes in the educational and leadership sectors, could suffice in producing momentum for proactive and strategic medium-term projects aimed at economic revival. The good news is that we do not have to start from scratch. The microeconomic framework in Kosovo is in place. Kosovo has low inflation, a stable currency (Euro), and sound fiscal policy. The trade regime is advanced; it is liberal and export oriented. Kosovo already has an operational, EU-like customs regime. The Kosovo government managed to record around 300 million EUR of budget surplus in 2003, thanks to constantly improving revenue collection mechanisms.

Not only are the dangers associated with Kosovo's level of unemployment outstanding in and of themselves, but they also create spill-over effects and negatively impact other reform processes, like democratization and social reconciliation. Missing from the picture are substantial private investments in the production sector ${ }^{18}$-in modern economies, this is the sector that employs the highest percentage of the workforce, and also contributes substantially to a state's GDP. Part of the problem has to do with poor education, which then results in unskilled labor and leadership. The educational system of Kosovo is run down and in urgent need of new funds and programs. Projects such as the American University in Kosovo and the Kosovo Center for Computer Studies (funded by Cisco Systems) have recently been set up. ${ }^{19}$ The problem is that they remain few and far between.

A skilled workforce, trained to participate in a globally integrated and competitive market system, is a precondition for attracting private investment into the production sector. Otherwise, the costs associated with educating and training the labor drive up the start-up costs too much, cutting into the profit margin. A modern educational system with an emphasis on liberal economic trends, business management, and IT is an ideal medium-term investment for upgrading Kosovo's unskilled labor force.

In the short term, the emphasis should be on risk insurance. At present investorsforeign as well as domestic - are reluctant to enter the production market for two reasons: high overhead and high interests rates, which banks are placing on longer-term loans. While changing the first is impossible in the immediate term for obvious reasons (infrastructure and educational systems take time before they can be (re)built), banks can be given a reason to loan capital on terms that are conducive to business development. It is impossible for the private sector to grow when borrowing occurs at high

17 Consider that Kosovo is currently governed from five distinct centers of power: UNMIK, PISG, Belgrade, New York, and Brussels.

18 An indication that the production sector is not working is the high trade imbalance. In 2003, Kosovo had imports in the amount of 968.5 million EUR and exports of a mere 36.2 million EUR. This equals 932.3 million EUR in trade deficit, suggesting that Kosovo's production sector is somewhat less than fully functional.

19 Nicholas Wood, "University in Kosovo has American Accent," International Herald Tribune (11 October 2003). 
interest rates, which in fact means that companies are losing money (see Figure 1). Obviously, when investing their money, banks want to maximize the return/risk ratio. Since in Kosovo they can exhaust all their assets investing them in profitable, shortterm consumer loans, or working capital loans for businesses, they are not interested in making long-term loans to underdeveloped companies, which are naturally perceived as higher risk. Although this is optimal behavior from the banks' point of view, it is not so from that of society: "The society, unlike banks, will have an interest in the growth of the production sector. Thus, we have a case of a market failure in providing societyoptimal outcomes. $" 20$

Through the provision of partial repayment guarantees for production-sector credits, the international community could make it possible for Kosovar enterprises to grow. Enterprises would be able to obtain loans at interest rates lower than the rates of return on their investments, and at maturity rates long enough to finance longer production-development cycles. Consequently, many Kosovar companies would move from the infant development stage to a more mature one, making it profitable for banks to extend them credit at lower interest rates. However, without an intervention by extra-market forces, it might take decades or more for this to happen.

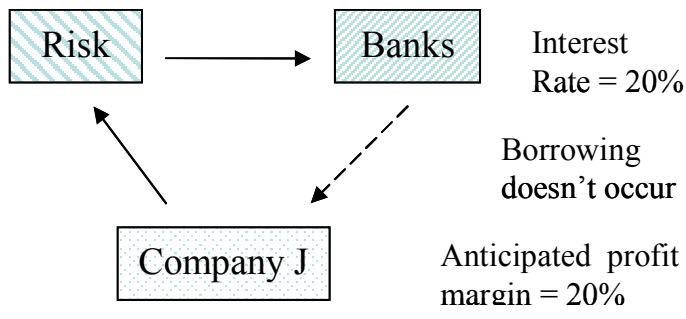

If Company $\mathrm{J}$ calculates a 20 percent profit margin over a period of the next five years, and the bank is willing to sign off a long-term loan at a 20 percent interest rate, the company has no interest in purchasing capital or fixed assets as the risk is too high. The question is how to affect perceived risk from the perspective of the banks in order for them to offer loans that are conducive to business development.

Figure 1: The vicious circle of risk, lending, and borrowing.

\section{Conclusion}

Obviously, Kosovo has real short-term needs, which may have less to do with questions of final status than most in the international community now suspect. Yes, there is a high level of local dissatisfaction with the UNMIK mission, but much of this frustration, it could be argued, has to do with the slow pace of progress in the economic wellbeing of Kosovo's citizens (both Albanians and Serbs); a market functioning far below its actual potential; a lack of coordination between various centers of authority and power; a slow privatization process; and no real progress in improving the technologi-

${ }^{20}$ Borut Grgic conversations with Orhan Niksic, Economic Policy Advisor, UNMIK Pillar IV. 
cal base of the market (i.e., education and other factors that would drive up the productivity of workers or capital).

Rather than insisting on a territorial solution to Kosovo's evidently economic problems, the international community must think about short- and medium-term market needs, and how to adjust its approach so as to build a Kosovo that is not only viable in the strictest political sense, but also self-sustainable in the long run. This means:

- Thinking of solutions that will increase the central budget and the country's GDP before adding additional municipalities onto the government payroll.

- Managing the privatization effort better, particularly in the service industry, where many local shops, restaurants, and bars remain unregistered and do not file for taxes. Ways to redefine the role of the KTA (Kosovo Trust Agency), and overcoming Belgrade's objections to the privatization of major SOEs should also be considered.

- Improving the education base upon which a functioning institutional unit can be built before declaring Kosovo an independent state, or transferring all competencies to the local level.

- Increasing the authority of the SRSG in order to help streamline and push difficult reforms before declaring the office irrelevant and an obstacle to reforms.

In the medium term it is important to insist on locally funded (or funded through grants) projects for infrastructural and other development. It seems unreasonable for Kosovo to pursue these projects through borrowing alone. Heavy borrowing in the near term, in order to overcome certain economic disadvantages, means budget restrictions in the long term. While there are certain projects where borrowing makes sense because of opportunity costs, a state's relationship with international financial institutions must be a rational one.

While the political momentum may be in favor of finalizing issues of status, the reality on the ground shows a different picture: a population that is growing younger, poorer, and more desperate. Resolving economic inefficiencies through territorial divisions will not create jobs, nor will it bring investment into Kosovo. This is a nineteenth-century nationalistic approach to a modern problem, and thus unsustainable in the fullest sense of the term. 
THE QUARTERLY JOURNAL

\section{Bibliography}

Brownlie, Ian. Implied Recognition In Principles of Public International Law. 6th ed. New York: Oxford University Press, 2003.

Gordy, Eric D.. The Culture of Power in Serbia: Nationalism and the Destruction of Alternatives. University Park, PA: Penn State University Press, 1999.

Judah, Tim. The Serbs: History, Myth, and the Destruction of Yugoslavia . New Haven, CT: Yale University Press, 1997.

Wood, Nicholas. "University in Kosovo has American Accent." International Herald Tribune (2003). 